Do Some Forms of Financial Flows Help Protect from Sudden Stops?

Andrei Levchenko and Paolo Mauro 

IMF Working Paper

Research Department

\title{
Do Some Forms of Financial Flows Help Protect from Sudden Stops?
}

\author{
Prepared by Andrei Levchenko and Paolo Mauro ${ }^{1}$
}

September 2006

\begin{abstract}
This Working Paper should not be reported as representing the views of the IMF. The views expressed in this Working Paper are those of the author(s) and do not necessarily represent those of the IMF or IMF policy. Working Papers describe research in progress by the author(s) and are published to elicit comments and to further debate.
\end{abstract}

There is a debate on whether some forms of financial flows offer better crisis protection than others. Using a large panel of advanced, emerging, and developing countries during 1970-2003, this paper analyzes the behavior of various types of flows: foreign direct investment (FDI), portfolio equity investment, portfolio debt investment, other flows to the official sector, other flows to banks, and other flows to the non-bank private sector. Differences across types of flows are limited with respect to volatility, persistence, cross-country comovement, and correlation with growth at home or in the world economy. However, consistent with conventional wisdom, FDI is found to be the least volatile form of financial flows when taking into account the average size of net or gross flows. The differences are striking during "sudden stops" in financial flows (defined as drops in total net financial inflows by more than 5 percentage points of GDP compared with the previous year): in such episodes, FDI is remarkably stable; portfolio equity also seems to play a limited role; portfolio debt experiences a reversal, though it recovers relatively quickly; and other flows (including bank loans and trade credit) experience severe drops and remain depressed for a few years.

JEL Classification Numbers: F21; F33; F36

Keywords: capital flows; crises; foreign direct investment

Author(s) E-Mail Address: alevchenko@imf.org; pmauro@imf.org

\footnotetext{
${ }^{1}$ The authors are grateful to Martín Minnoni for research assistance, and Torbjörn Becker, Philip Lane, Enrique Mendoza, Gian Maria Milesi-Ferretti, Jonathan Ostry, and especially André Faria and Romain Rancière for helpful suggestions.
} 


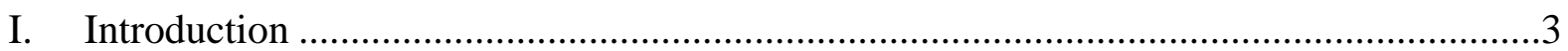

II. Behavior of Different Types of Financial Flows ......................................................4

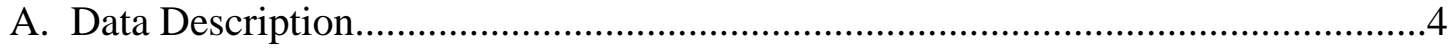

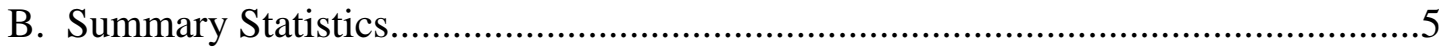

III. Behavior during Sudden Stops in Financial Flows ..................................................10

A. Defining Sudden Stops in Financial Flows ......................................................10

B. Behavior of Different Types of Financial Flows Around Sudden Stops ...............11

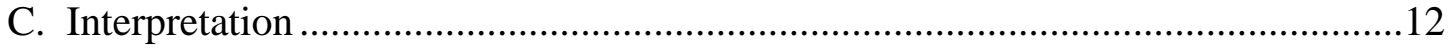

IV. Conclusions and Possible Extensions .....................................................................18

Tables:

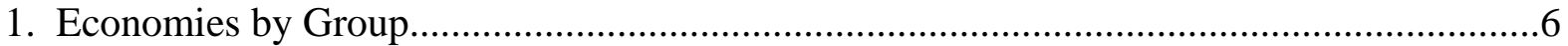

2. Financial Account and its Sub-Components, 1970-2003 .............................................7

3. Number of Large Worsenings During Sudden Stops, by Flow Type ..............................13

Figures:

1. Composition of Financial Flows Around All Sudden Stops, 1980-2004.........................14

2. Composition of Financial Flows Around the August 1998 Russia/LTCM Crisis ...............15

3: Consensus Forecasts for the Following Year (Real GDP Growth in Percent) ...................16

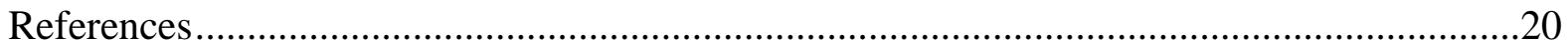




\section{INTRODUCTION}

The composition of a country's external liabilities - that is, the relative shares of foreign direct investment, portfolio equity, and external debt-may be an important determinant of its economic performance and vulnerability to crisis as a result of two possible types of mechanisms. First, the payments associated with some types of external liabilities have more desirable cyclical properties than those implied by others (Rogoff, 1999): with equity-like forms of finance, such as portfolio equity or foreign direct investment, payments are lower when economic performance is worse, whereas with debt contracts the same coupon payment is envisaged regardless of the state of the economy. ${ }^{2}$ Equity finance thus makes it possible for domestic producers to share risk with foreign investors, thereby helping stabilize domestic consumption and improving domestic producers' ability to undertake riskier but more profitable projects. Second, some forms of flows may behave in a more desirable manner than others. For example, foreign direct investment has traditionally been viewed as more stable, and thus less likely to trigger financial crisis, than portfolio financial flows. At the same time, some empirical studies have cast doubt on the relevance of labels such as "shortterm" and "long-term" flows for the volatility or predictability of financial flows (Claessens and others, 1995).

While recognizing that the first mechanism—-payments with desirable cyclical properties_-is also of key importance, this paper focuses squarely on the second mechanism: the behavior of the various types of financial flows. Several previous studies have already considered some of the properties of at least some types of international financial flows, and in what follows we relate our findings to those obtained by other researchers. Nevertheless, the objective in this paper is to provide the most detailed, comprehensive, and up-to-date exercise analyzing the behavior of various types of financial flows-especially for instances of sudden stop (defined as reversals in total financial flows by more than 5 percentage points of GDP compared with the previous year).

The estimates presented below yield a somewhat mixed picture, suggesting that some, but not all, aspects of the conventional wisdom are confirmed by systematic empirical analysis. The key results are the following:

- $\quad$ Consistent with earlier results by Claessens and others (1995), the various types of financial flows do not seem to differ significantly with regard to persistence, procyclicality, responsiveness to G-7 growth or US interest rates, or comovement across emerging markets.

\footnotetext{
${ }^{2}$ Moreover, in the event of an exchange rate crisis, foreign currency debt requires even greater payments in domestic currency terms, at a time when output usually declines. On the other hand, default or, for domestic currency debt, inflation, are ways in which the burden of debt can be reduced in bad times.
} 
- $\quad$ Consistent with conventional wisdom, FDI is the least volatile form of financial flows, when taking into account the average size of net or gross flows. At the same time, changes in FDI flows account for a large portion of changes in overall flows, reflecting FDI's importance as one of the largest sources of net flows to emerging and developing countries.

- $\quad$ The various types of flows behave very differently during sudden stops. FDI remains remarkably stable and plays essentially no role in sudden stops-an especially striking result considering that FDI represents a large share of total financial flows. Similarly, portfolio equity seems to play a limited role in sudden stops. Portfolio debt does experience a reversal, though it recovers relatively quickly after the sudden stop. Bank lending flows and official flows experience severe drops and remain depressed for several years after sudden stops.

A few previous studies have directly analyzed some aspects of the behavior of different types of financial flows, often focusing on important episodes. ${ }^{3}$ Claessens and others (1995), in what is probably the most thorough analysis of stylized facts in this context, fail to find significant differences across types of flows. At the same time, Chuhan and others (1996) and the World Bank (1999) report evidence suggesting that FDI may be more resilient than shortterm flows in response to financial disturbances; Sarno and Taylor (1999) find FDI to be more persistent than other types of flows; and Lipsey (2001) shows that FDI was relatively stable in the crises affecting Latin America in 1982, Mexico in 1994, and East Asia in 1997. Our objective is to update and build upon such studies and to gather a more comprehensive range of stylized facts, including an analysis of the behavior of financial flows in "sudden stop time,” using an approach loosely analogous to that taken by event studies.

\section{BEHAVIOR OF DifFERENT TyPES OF FinANCIAL FLOWS}

\section{A. Data Description}

This paper analyzes 1970-2003 data on the financial account and six of its components: (i) Foreign Direct Investment (FDI); (ii) Portfolio Debt Investment (PDI); (iii) Portfolio Equity Investment (PEI); (iv) Other Net Flows to the Domestic Official Sector (the net flows arising from net purchases of foreign assets by the domestic monetary authorities and general government, and net purchases by foreign residents of liabilities issued by the domestic monetary authorities and general government); (v) Other Net Flows to Domestic Banks (the

\footnotetext{
${ }^{3}$ Other studies have addressed complementary questions. Fernández-Arias and Hausmann (2001) consider the relationship between the composition of financial flows and the frequency of crises; they find that the share of FDI in total finance is associated with a lower frequency of crisis in developing countries, though they argue that the true underlying determinant of the likelihood of crisis is the currency denomination and maturity of liabilities. Faria and Mauro (2004) analyze the long-run determinants of the composition of countries' external liability structures, and find that institutional quality tends to be positively associated with the share of FDI and, especially, portfolio equity, in total liabilities.
} 
net flows arising from net purchases of foreign assets by domestic banks, and net purchases by foreign residents of liabilities issued by domestic banks); and (vi) Other Net Flows to the Non-Bank Private Sector (e.g. trade credits and bank flows to the non-bank private sector). ${ }^{4}$ All flows are net, ${ }^{5}$ and reported in current U.S. dollars; the data are drawn from the IMF's Balance of Payments (BOP) database (Analytic Presentation, 5th edition of the Balance of Payments Manual). All flows exclude Exceptional Financing, Use of IMF credit, and Changes in Reserves. Throughout the analysis below, the flows are normalized by GDP in current U.S. dollars (taken primarily from the World Bank's World Development Indicators database, and supplemented with data from the IMF's World Economic Outlook database). All data were checked for quality, dropping outliers and unusable observations. The full sample includes 153 countries (Table 1), though only less than half of the countries in the sample have reliable data for a sufficiently long time series. The summary statistics presented below are based on annual data for 1970-2003; all the main results hold for the subperiod 1990-2003. Similar patterns are also obtained (not reported, for the sake of brevity) using quarterly data for a smaller sample of countries.

\section{B. Summary Statistics}

\section{Average Net Flows}

Considering the average financial account balance for each country in 1970-2003, and taking the cross-country median within each country group over the period, developing countries had the largest net inflows, followed by emerging markets, and then advanced countries (Table 2). This pattern is even more pronounced for FDI, which has not been a net source of finance for advanced countries. By contrast, emerging markets received net FDI inflows averaging about 1.3 percentage points of GDP yearly, and developing countries received about 2.3 percentage points. The results (not reported for the sake of brevity) are similar when considering 1990-2003 only, and suggest that the relative importance of FDI as a source of net inflows for emerging and developing countries has, if anything, increased in the last decade.

\section{Volatility}

Using the standard deviation of net flows (computed for each country, over 1970-2003) as a measure of volatility, financial flows are found to be substantially more volatile in emerging and developing countries. The cross-country median of the standard deviation of the financial account balance is 2.9 percentage points of GDP for advanced countries, and 4.5 percentage points for emerging markets and developing countries. This corroborates findings by previous studies (Broner and Rigobon, forthcoming; Prasad and others, 2003). The ranking

\footnotetext{
${ }^{4}$ The sample period was chosen on the basis of data availability and quality.

${ }^{5}$ We analyze net, rather than gross, flows, because sudden stops are a concept based on the net financial account. More generally, crises and financing difficulties result from changes in net flows.
} 
Table 1. Economies by Group

\begin{tabular}{|c|c|c|c|}
\hline Advanced & Emerging & Developing & \\
\hline Australia & Argentina & Albania & Jamaica \\
\hline Austria & Brazil & Algeria & Kazakhstan \\
\hline Belgium-Luxembourg & Bulgaria & Angola & Kenya \\
\hline Canada & Chile & Antigua and Barbuda & Kuwait \\
\hline China P.R. Hong Kong & China P.R. Mainland & Armenia & Kyrgyz Republic \\
\hline Cyprus & Colombia & Aruba & Lao's Peoples Dem. Rep. \\
\hline Denmark & Cote d'Ivoire & Azerbaijan & Latvia \\
\hline Finland & Czech Republic & Bahamas The & Lesotho \\
\hline France & Dominican Republic & Bahrain Kingdom of & Lithuania \\
\hline Germany & Ecuador & Bangladesh & Macedonia F.Y.R. \\
\hline Greece & Egypt & Barbados & Madagascar \\
\hline Iceland & El Salvador & Belarus & Malawi \\
\hline Ireland & Hungary & Belize & Maldives \\
\hline Israel & India & Benin & Mali \\
\hline Italy & Indonesia & Bolivia & Malta \\
\hline Japan & Jordan & Botswana & Mauritania \\
\hline Netherlands & Korea & Burundi & Mauritius \\
\hline New Zealand & Malaysia & Cambodia & Moldova \\
\hline Norway & Mexico & Cameroon & Mongolia \\
\hline Portugal & Morocco & Cape Verde & Mozambique \\
\hline Singapore & Nigeria & Central African Rep. & Namibia \\
\hline Spain & Oman & Chad & Nepal \\
\hline Sweden & Pakistan & Comoros & Netherlands Antilles \\
\hline Switzerland & Panama & Congo Republic of & Nicaragua \\
\hline United Kingdom & Peru & Costa Rica & Niger \\
\hline \multirow[t]{20}{*}{ United States } & Philippines & Croatia & Papua New Guinea \\
\hline & Poland & Dominica & Paraguay \\
\hline & Russia & Estonia & Romania \\
\hline & Saudi Arabia & Fiji & Rwanda \\
\hline & Slovak Republic & Gabon & Sao Tome Principe \\
\hline & South Africa & Gambia, The & Senegal \\
\hline & Sri Lanka & Georgia & Seychelles \\
\hline & Thailand & Ghana & Sierra Leone \\
\hline & Tunisia & Grenada & Slovenia \\
\hline & Turkey & Guatemala & Solomon Islands \\
\hline & Ukraine & Guinea & Sudan \\
\hline & Uruguay & Guyana & Swaziland \\
\hline & Venezuela, Rep. Bol. & Haiti & Syrian Arab. Republic \\
\hline & Zimbabwe & Honduras & Tanzania \\
\hline & & & Togo \\
\hline & & & Tonga \\
\hline & & & Trinidad and Tobago \\
\hline & & & Uganda \\
\hline & & & Vanuatu \\
\hline & & & Vietnam \\
\hline
\end{tabular}

Note: Advanced countries are defined as in the IMF's World Economic Outlook, except for Korea which for the purpose of the empirical analysis is classified as an emerging market rather than advanced to capture the experience of its 1997-98 crisis; the remaining countries are considered emerging markets if they are included in either the (stock market based) International Financial Corporation's Major Index (2005) or JPMorgan's EMBI Global Index (2005) (which includes countries that issue bonds on international markets); the remaining countries are classified as developing. Countries in bold are in our main sample. 
Table 2. Financial Account and its Sub-Components, 1970-2003

\begin{tabular}{|c|c|c|c|c|c|c|c|}
\hline & $\begin{array}{r}\text { Financial } \\
\text { Account }\end{array}$ & FDI & PDI & PEI & $\begin{array}{c}\text { Flows to } \\
\text { Official }\end{array}$ & $\begin{array}{c}\text { Flows to } \\
\text { Banks }\end{array}$ & $\begin{array}{c}\text { Flows to } \\
\text { Other }\end{array}$ \\
\hline \multicolumn{8}{|l|}{ Average of Capital Flows } \\
\hline Advanced & 1.34 & 0.07 & 0.25 & -0.20 & 0.01 & 0.41 & 0.10 \\
\hline Emerging & 2.12 & 1.30 & 0.21 & 0.15 & 0.10 & 0.01 & 0.04 \\
\hline Developing & 3.15 & 2.24 & -0.07 & 0.00 & 0.86 & -0.14 & 0.57 \\
\hline \multicolumn{8}{|l|}{ Standard Deviation } \\
\hline Advanced & 2.88 & 1.35 & 2.09 & 1.56 & 0.80 & 2.31 & 1.86 \\
\hline Emerging & 4.38 & 1.50 & 1.20 & 0.63 & 1.89 & 1.32 & 1.95 \\
\hline Developing & 4.55 & 2.11 & 0.92 & 0.33 & 2.22 & 1.14 & 1.90 \\
\hline \multicolumn{8}{|l|}{ Coefficient of Variation } \\
\hline Advanced & 1.34 & 2.22 & 2.28 & 3.25 & 2.66 & 5.02 & 5.55 \\
\hline Emerging & 1.83 & 1.00 & 3.18 & 1.96 & 3.16 & 7.22 & 3.61 \\
\hline Developing & 1.32 & 0.92 & 3.07 & 2.14 & 2.39 & 3.62 & 2.15 \\
\hline \multicolumn{8}{|c|}{ Correlation with Domestic Growth } \\
\hline Advanced & 0.08 & -0.02 & -0.10 & 0.03 & -0.02 & 0.17 & -0.02 \\
\hline Emerging & 0.23 & 0.10 & -0.03 & 0.09 & -0.03 & 0.17 & 0.20 \\
\hline Developing & 0.15 & 0.17 & -0.08 & 0.03 & -0.02 & 0.04 & 0.11 \\
\hline \multicolumn{8}{|l|}{ Correlation with G7 Growth } \\
\hline Advanced & 0.03 & 0.00 & -0.01 & 0.00 & -0.01 & 0.02 & -0.01 \\
\hline Emerging & -0.09 & -0.09 & -0.09 & 0.11 & -0.04 & -0.07 & -0.06 \\
\hline Developing & 0.02 & 0.02 & 0.01 & 0.22 & 0.03 & -0.02 & -0.01 \\
\hline \multicolumn{8}{|c|}{ Correlation with US 1 year Tbill } \\
\hline Advanced & 0.24 & 0.08 & 0.07 & 0.09 & 0.03 & 0.00 & 0.16 \\
\hline Emerging & 0.08 & -0.29 & -0.06 & 0.08 & 0.27 & 0.02 & 0.13 \\
\hline Developing & 0.07 & -0.16 & 0.02 & 0.15 & 0.21 & 0.02 & 0.04 \\
\hline \multicolumn{8}{|l|}{ Persistence (AR1 Pooled) } \\
\hline Advanced & 0.68 & 0.33 & 0.35 & 0.37 & 0.40 & 0.37 & 0.41 \\
\hline Emerging & 0.52 & 0.51 & 0.02 & 0.39 & 0.42 & 0.11 & 0.47 \\
\hline Developing & 0.51 & 0.35 & 0.51 & 0.41 & 0.48 & 0.17 & 0.37 \\
\hline \multicolumn{8}{|l|}{ First Principal Component } \\
\hline Advanced & 0.30 & 0.36 & 0.23 & 0.37 & 0.20 & 0.27 & 0.19 \\
\hline Emerging & 0.24 & 0.40 & 0.28 & 0.34 & 0.25 & 0.19 & 0.21 \\
\hline Developing & 0.28 & 0.32 & 0.36 & 0.35 & 0.27 & 0.17 & 0.18 \\
\hline
\end{tabular}

Sources: IMF, Balance of Payments Statistics (all financial flows); World Bank, World Development Indicators and IMF, World Economic Outlook (GDP). See the text for details.

Notes: All statistics (except persistence and the share of variation accounted for by the first principal component) are computed for each country over 1970-2003. The data reported are medians across countries within each group. All flows are net and normalized by total GDP for each year. The coefficient of variation of a series is the standard deviation divided by the mean: it is computed for each country separately, and this table reports the median across countries. The measure of persistence for each variable is the slope coefficient in a panel (fixed effects) regression of the variable of interest on its lagged value. The share of variation accounted for by the first principal component is a measure of comovement across countries within each group: it is the share of total variation in a set of series that can be explained by a common component. The sample consists of 24 advanced economies, 25 emerging markets, and 17 developing countries, though the number of developing countries is lower for some subcomponents. 
by standard deviation is the same for FDI and other flows to the official sector. However, both PDI and PEI are 2 and 5 times more volatile in advanced countries than in developing countries, respectively, with emerging market countries somewhere inbetween. Comparing across flows, FDI is the least volatile type of flow in advanced countries, with the exception of other flows to the official sector. For emerging markets, on the other hand, FDI is more volatile than PDI or PEI. For developing countries, other net flows to the official sector are the most volatile, followed closely by FDI. Comparing across flows, however, it is important to take into account the size of the various types of flows, by using the coefficient of variation (the standard deviation divided by the mean). On that basis, FDI is the most stable of all flows to emerging and developing countries, with a (cross-country median) coefficient of variation near 1, compared to 2-3 for PDI and PEI, or 5-7 for other flows to the official sector, other flows to banks, and other flows to the non-bank private sector (see also Wei, 2001). ${ }^{6}$

\section{Correlations}

Table 2 also reports correlations of financial flows with domestic GDP growth, G7 growth, and U.S. interest rates (the 1-year T-bill rate). The coefficients of correlation between financial flows and these variables turn out to be quite small, except as noted below. Financial flows are mildly procyclical (with respect to domestic GDP growth) in emerging market and developing countries (see also Albuquerque and others, 2005). In developing countries, FDI displays the highest correlation with growth, though the coefficient is still small at 0.2 . For emerging markets, most procyclical are other flows to the official sector and other flows to the non-bank private sector. The only type of flow that exhibits significant correlation with G-7 growth is PEI for emerging markets ( 0.1$)$ and developing countries (0.2). The U.S. interest rate is correlated with the inflows into advanced countries, with a coefficient of 0.2 , and is virtually uncorrelated with the financial account of emerging and developing countries. FDI is negatively correlated with the U.S. interest rate, in both emerging markets (correlation of -0.3) and developing countries (correlation of -0.16). Other studies, such as Fernández-Arias (1996), find — using higher frequency data for shorter time periods - that foreign interest rates do matter for financial flows. The present exercise shows that foreign interest rates matter less at the yearly frequency, a result also reported by Broner and Rigobon (forthcoming). Different kinds of financial flow are also uncorrelated or weakly negatively correlated with each other, a pattern that holds for all country groups, consistent with the results obtained by Claessens and others (1995). This may suggest that different types of flows are substitutes rather than complements, or that reclassifications (say, between FDI and porfolio equity) are frequent.

\footnotetext{
${ }^{6}$ One possible problem with calculating the coefficient of variation is that average net inflows are often quite close to zero. To check robustness, we used two alternative measures of relative volatility. First, we computed the coefficient of variation for gross financial inflows. Second, we normalized the standard deviation of net flows by the average gross flows. The conclusions are virtually the same.
} 


\section{Persistence}

In order to investigate the persistence properties of financial flows, autoregressive coefficients were calculated on pooled data for each relevant country group, using a fixed effects regression with the first lag on the right-hand side. ${ }^{7}$ The financial account balance is more persistent in advanced countries, with an autoregressive (AR(1)) coefficient of 0.7, than it is in emerging markets and developing countries, where the AR(1) coefficient is estimated at 0.5 . For advanced countries, the $\mathrm{AR}(1)$ coefficient is also quite similar across flows, ranging between 0.3-0.4. For emerging markets, the most persistent type of flow is FDI, with an $\mathrm{AR}(1)$ coefficient of 0.5 ; and the least persistent is PDI, with a coefficient of virtually zero. For developing countries, FDI has an AR(1) coefficient of 0.35, with the coefficients for PDI, PEI, and other flows lying between 0.2-0.5. These estimates are close to those in Obstfeld and Taylor (2004) and Broner and Rigobon (forthcoming), though the latter find that total financial flows are more persistent in emerging and developing countries than in advanced countries.

\section{Principal Components Analysis}

The interrelationships of financial flows across regions and income groups are analyzed using principal components analysis, focusing on the share of variation explained by the first principal component for each country group or region. For total financial flows, the patterns across developed and developing countries are quite similar, with the first principal component accounting for 25 to 30 percent of the variation in financial flows. Comparing across flows, FDI and PEI display the largest common component for advanced countries; for emerging markets, FDI has the largest common component; for developing countries, FDI, PDI, and PEI are roughly similar in this respect. Overall, however, there are no pronounced differences across types of flow in the importance of the common component. ${ }^{8}$

To recapitulate the evidence based on the summary statistics reported thus far, equity-like forms of finance seem relatively desirable because the payments they imply tend to be associated with the recipient country's ability to repay. In addition, although the behavior of the various types of financial flow does not differ much in some important respects, FDI

\footnotetext{
${ }^{7}$ As an alternative, we estimated AR(1) regressions for each country separately. The disadvantage of the pooled approach is that it constrains the AR(1) coefficient to be the same for each country group. The advantage is that it allows for inclusion of countries for which only a short time series is available. The results obtained by performing the exercise country-by-country were similar to those reported here.

${ }^{8}$ Although Calvo and others (1993) find that the first principal component can account for 60 to 80 percent of variation in financial flows, their use of monthly data for a shorter time span (four years) on a Latin American sample may explain the difference in results. Albuquerque and others (2005) show that the share of variation in FDI that is attributable to global factors has increased dramatically over the past two decades.
} 
flows in particular seem relatively stable (when controlling for the size of the flows). As we report below, FDI flows are also strikingly impervious to sudden stops.

\section{BEHAVIOR DURING SUDDEN STOPS IN FinANCIAL FLOWS}

This section shows that differences in the behavior of the various types of financial flows become more pronounced during "sudden stop" events.

\section{A. Defining Sudden Stops in Financial Flows}

Definitions of sudden stops generally focus on large and rapid changes in financial flows. ${ }^{9}$ The present study defines a sudden stop as a worsening in the financial account balance by more than 5 percentage points of GDP compared with the previous year. (The main results hold using alternative numerical thresholds.)

A key advantage of the definition used in the present study is its simplicity. It should be noted, however, that in a few cases countries maintain a positive financial balance even after a large and rapid worsening. These "sudden slowdowns" in inflows are kept as part of the list of sudden stops because, like other sudden stops, they require a decumulation of reserves or a reduction in the current account deficit. Another potential caveat is that in principle some sudden stops in financial inflows may be viewed primarily as the mirror image of improvements in the current account balance-especially windfall gains in exports revenues resulting from booms in commodity prices. Although we include commodity exporters in the sample, none of the sudden stops that we analyze seem to meet this description.

Alternative definitions of sudden stops are possible: for example, a decline in flows by more than two standard deviations, based on the individual country's distribution (Calvo, Izquierdo, and Mejia, 2004). Other things equal, however, a threshold based on percentage points of GDP will tend to identify more episodes in countries with volatile financial flows, whereas a threshold based on standard deviations will tend to identify a considerable number of episodes even for countries whose flows are stable by international standards. In an attempt to alleviate this problem, some studies use a combination of criteria, such as the 5 percentage point of GDP cutoff in combination with the change being greater than one standard deviation (Guidotti, Sturzenegger, and Villar, 2004). While such definitions are reasonable, we prefer our simpler definition and have checked, to the best of our abilities, that our key results are robust to changes in the definition of sudden stop.

More generally, regardless of the exact definition, the interpretation of the results will depend on the direction of causality. Arguably, an intuitive and interesting question is which types of financial flows account for a sudden stop prompted by an exogenous fall in the supply to

\footnotetext{
${ }^{9}$ According to a bankers' saying, "it is not speed that kills, it is the sudden stop.” See Dornbusch, Goldfajn and Valdés (1995).
} 
emerging markets, rather than a sudden stop caused by worsening expectations regarding a country's economic performance. While causality cannot be established definitively, we show below that inspection of growth forecast data since 1990 suggests that our list of sudden stops does not include any obvious instances in which the stop was triggered by worsening growth expectations.

\section{B. Behavior of Different Types of Financial Flows Around Sudden Stops}

The various types of financial flows display striking differences in behavior in "sudden stop time.” Figure 1 summarizes the information from the 33 sudden stop episodes in 1980-2002 for which all six sub-components of the financial account are available for at least a 5-year period around the sudden stop year. For each episode, the data are converted to "sudden stop" time, with $t=0$ being the year the sudden stop occurred. For each type of financial flow, the cross-episode average (solid line) and standard error (that is, the standard deviation divided by the number episodes_-dotted lines) are computed. (The data are first regressed on country and year dummies to remove country-specific means and global developments from the data. The main results are largely unaffected by this procedure.)

FDI plays almost no role in sudden stops in financial flows: it remains strikingly stable, even though it represents a large share of total financial flows. ${ }^{10}$ Similarly, portfolio equity seems to play a limited role in sudden stops. Portfolio debt does experience a reversal, though it recovers relatively quickly after sudden stops. Other flows to the official sector, banks, and especially the non-bank private sector experience severe drops, and remain depressed for a few years after sudden stops.

An alternative way of gauging the role played by each type of flow in sudden stops is to consider the number of instances in which a type of flow worsened by more than a given threshold (say, in percentage points of GDP) during sudden stop episodes (Table 3). We consider the 85 sudden stops for which data on some type of flow are available (top panel) and the 33 sudden stops (as in Figure 1) for which data on all types of flow are available (bottom panel). This confirms that FDI plays a limited role in sudden stops, whereas "other flows” display more frequent large worsenings. Portfolio debt displays relatively frequent large drops, especially taking into consideration its relatively small size in normal times.

A similar message emerges when considering the response of different components of financial flows at the quarterly frequency around the Russian/LTCM crisis of August 1998, for all emerging market countries (see Figure 2, which — for the sake of brevity-only reports data for the countries whose financial account balance was most affected by the crisis.)

\footnotetext{
${ }^{10}$ We discuss below whether this result could be accounted for by "fire-sale FDI" (namely, FDI taking place in the aftermath of a crisis as cash-strapped domestic entrepreneurs sell to foreign investors who take advantage of the exchange rate devaluation).
} 
Again, FDI (the dotted line) remains remarkably stable in all countries, despite major worsening of the financial account balance (the solid line) and net flows of portfolio debt, portfolio equity, and other flows. The advantages of analyzing the Russian/LTCM crisis and its aftermath are that it may be viewed as a genuinely exogenous "sudden stops" (an unexpected event, unlikely to have been triggered by simultaneously worsening expectations of growth or other fundamentals in many emerging markets); and that its consequences may be tracked for all emerging markets, without imposing any numerical cutoff on the size of the financial account reversal. At the same time, a disadvantage is that the initial nature of the shock, a default on debt contracts, may have made it more likely to affect portfolio debt than other types of liabilities.

\section{Interpretation}

\section{Causality and Timing}

As mentioned above, the interpretation of our results regarding which components of financial flows account for sudden stops depends on the ultimate source of the sudden stop itself. If the sudden stop were driven by worsening expectations of economic growth, and if some types of flows were more closely related to growth prospects than others, then differences in resilience across types of flow in the face of sudden stops would arise naturally. If, instead, it were difficult to attribute sudden stops to changes in fundamentals in the countries affected, then one might be more willing to view some types of flows not merely as a vehicle but perhaps more as the source of instability. This would allow for an interpretation of the results consistent with the view that "fickle international investors" (Wei, 2001) are the source of vagaries in international financial flows, and that some forms of flows are more prone to reversals.

While we cannot conclusively establish causality, this section shows that for essentially all sudden stop episodes in our sample, there was no worsening in the Consensus Forecast economic growth for the following year (or the same year) even the same month as the sudden stop, for almost all countries for which monthly forecast data are available. ${ }^{11}$ Indeed, in most cases where the sudden stop was associated with an abrupt crisis reflected in the exchange rate or other asset prices, the Consensus Forecast growth began falling in a visible manner only the month after the crisis erupted (Figure 3). For the countries affected by the Asian crisis, forecast growth declined well after the beginning of the crisis in Thailand (July 1997). Similarly, for the countries affected by the Russian crisis, forecast growth declined only after the August 1998 crisis. The one notable exception was Argentina, where forecast growth began declining in the summer of 2001, about half a year prior to the full-blown

${ }^{11}$ For all sudden stop episodes in countries for which quarterly data are available, the results are confirmed by analyzing quarterly data on financial flows, identifying the first quarter when the sudden stop began, and checking that the preceding issue of the IMF's World Economic Outlook did not forecast a slowdown in economic growth for the country in question. 
Table 3. Number of Large Worsenings During Sudden Stops, by Flow Type

\begin{tabular}{|c|c|c|c|c|c|}
\hline & \multicolumn{5}{|c|}{$\begin{array}{l}\text { Number of large worsenings of given flow type } \\
\text { (thresholds in percentage points of GDP) }\end{array}$} \\
\hline & 1 p.p. change & 2 p.p. change & 3 p.p. change & 4 p.p. change & 5 p.p. change \\
\hline & \multicolumn{5}{|c|}{ out of 85 sudden stops } \\
\hline Foreign Direct Investment & 33 & 18 & 13 & 10 & 8 \\
\hline Portfolio Debt Investment & 21 & 16 & 10 & 6 & 5 \\
\hline Portfolio Equity Investment & 7 & 2 & 1 & 0 & 0 \\
\hline \multirow[t]{2}{*}{ Other Investments } & 79 & 75 & 73 & 67 & 60 \\
\hline & \multicolumn{5}{|c|}{ out of 33 sudden stops } \\
\hline Foreign Direct Investment & 13 & 9 & 5 & 2 & 2 \\
\hline Portfolio Debt Investment & 18 & 15 & 9 & 6 & 5 \\
\hline Portfolio Equity Investment & 6 & 1 & 1 & 0 & 0 \\
\hline Other Investments & 29 & 29 & 26 & 20 & 15 \\
\hline
\end{tabular}

Sources: IMF, Balance of Payments Statistics (all financial flows); World Bank, World Development Indicators and IMF, World Economic Outlook (GDP). See the text for details.

Notes: The table reports the number of instances in which each flow type fell by more than a given number of percentage points of GDP, as indicted, during times of sudden stop (defined as episodes when the financial account worsens by more than 5 percentage points of GDP). The top panel considers the 85 sudden stops for which data are available for some type of flow. The bottom panel considers the 33 sudden stops for which data are available for all types of flow.

crisis. Our interpretation of this pattern is that it substantially reduces the likelihood that sudden stops were caused by worsening country-specific fundamentals.

\section{Fire-Sale FDI}

Another potential concern is that perhaps a large portion of the resilience of FDI in the face of sudden stops might be accounted for by an increase in "fire-sale" FDI-a phenomenon for which existing evidence is based upon firm-level data regressions for a small set of Asian countries in the context of the 1997-98 crisis (Aguiar and Gopinath, 2005). ${ }^{12}$ While it is difficult to gauge the exact macroeconomic relevance of fire-sale FDI, two sets of considerations are in order here. First, FDI rose after sudden stops in two Asian countries, Korea and Thailand, where growth expectations improved rapidly soon after the crisis. In essentially all other cases in the sample, FDI remained strikingly stable. Occam's razor

\footnotetext{
12 "Fire-sale" FDI takes place in the aftermath of a crisis (typically involving a sharp currency depreciation), when foreign investors purchase domestic, cash-strapped firms at prices that tend to be below those based on long-run fundamentals.
} 
Figure 1. Composition of Financial Flows Around All Sudden Stops, 1980-2004 (In Percentage Points of GDP)
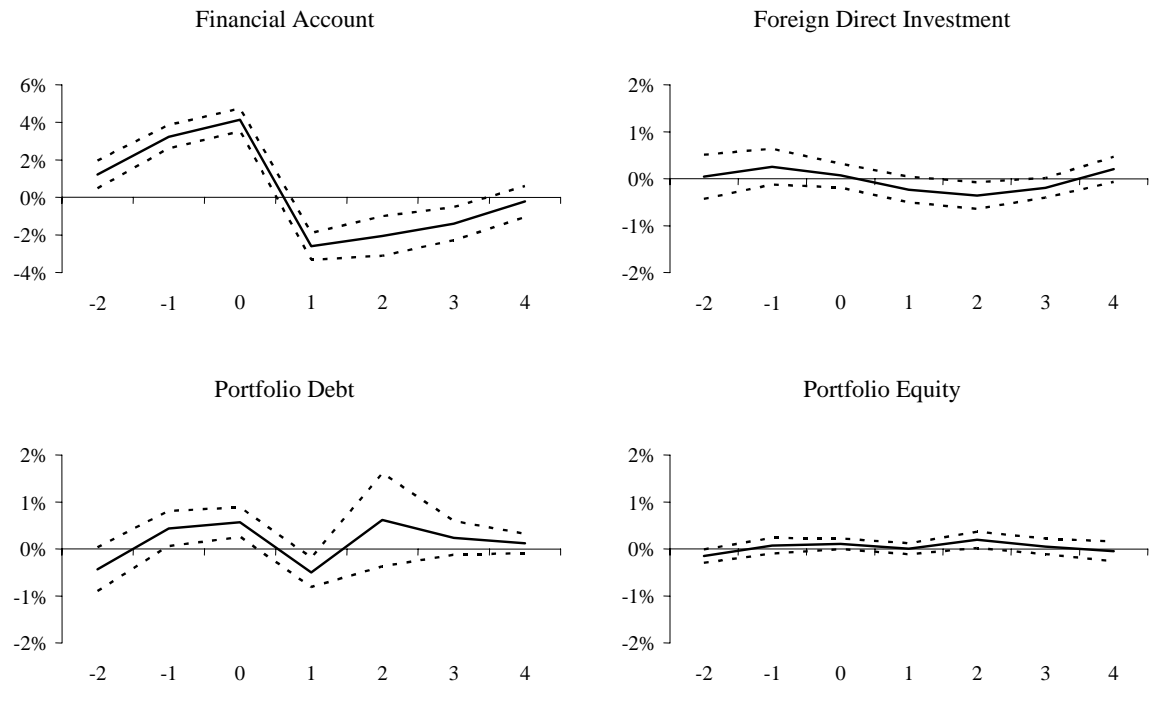

Other Net Flows to Official Sector

Other Net Flows to Banks
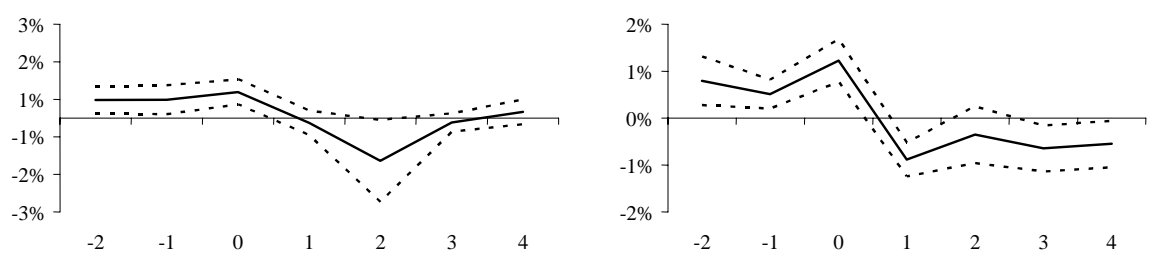

Other Net Flows to Private Non-banking Sector

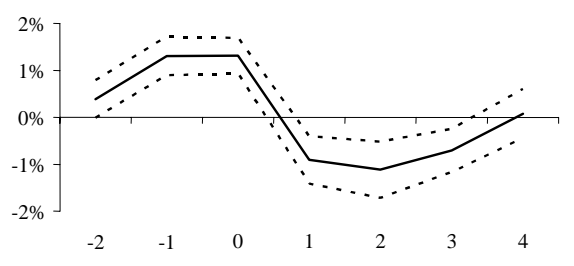

Source: IMF, Balance of Payments Statistics (analytic presentation).

Note: The behavior of different types of flows is illustrated in "sudden stop" time, with $\mathrm{t}=1$ being the year the sudden stop occurred. The solid line represents the average across episodes for each type of financial flow. The dotted lines are one standard error bands for the cross-country distribution for the given year (in event time) and type of flow. Sudden stops are reversals in the financial account by more than 5 percentage points of GDP. The sample is restricted to instances in which all six sub-components of the financial account are available for at least a 5-year period around the sudden stop year. The sample consists of 33 episodes: Argentina (2001); Barbados (1992, 2002); Brazil (1983); Chile (1991); Cote d'Ivoire (1983, 1996), Croatia (1998); Czech Republic (1996); Estonia (1998); Korea, Rep. (1997); Latvia (2000); Lithuania (1999); Mauritius (2001); Mexico (1995); Namibia (1991, 1999); Panama (2000); Peru (1998); Philippines (1997); Russian Federation (1998); Senegal (1982); Slovenia (1998); Swaziland (1993); Thailand (1982, 1997); Togo (1992); Turkey (1994, 2001); Ukraine (1998); and Venezuela (1980, 1989, 2002). For each type of capital flow, the entire available sample of countries and years is first regressed on a full set of country and year fixed effects to remove country-specific means and global developments from the data. All flows exclude Exceptional Financing, Use of IMF credit, and changes in reserves. 
Figure 2. Composition of Financial Flows Around the August 1998 Russia/LTCM Crisis
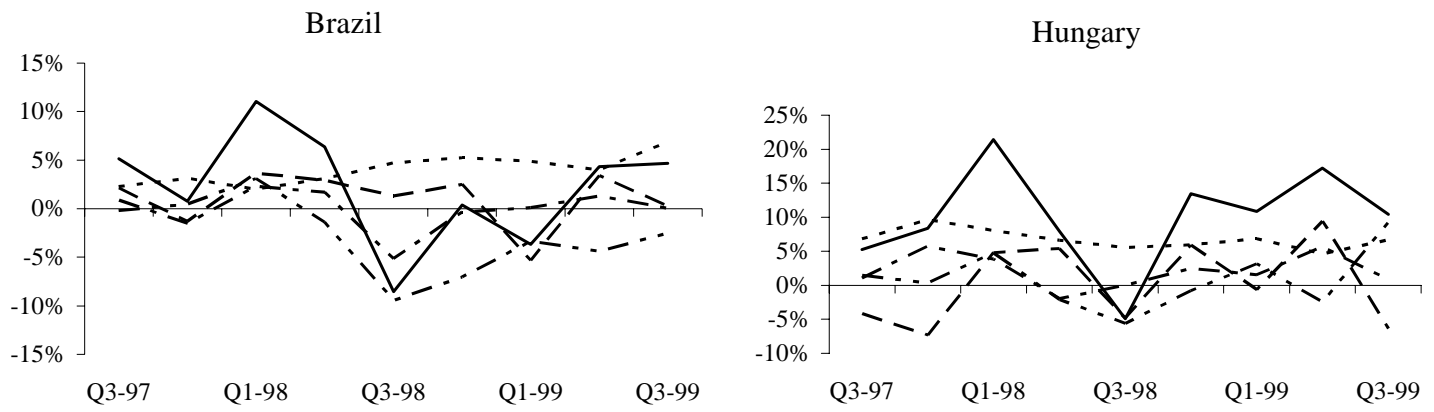

Philippines

Russia
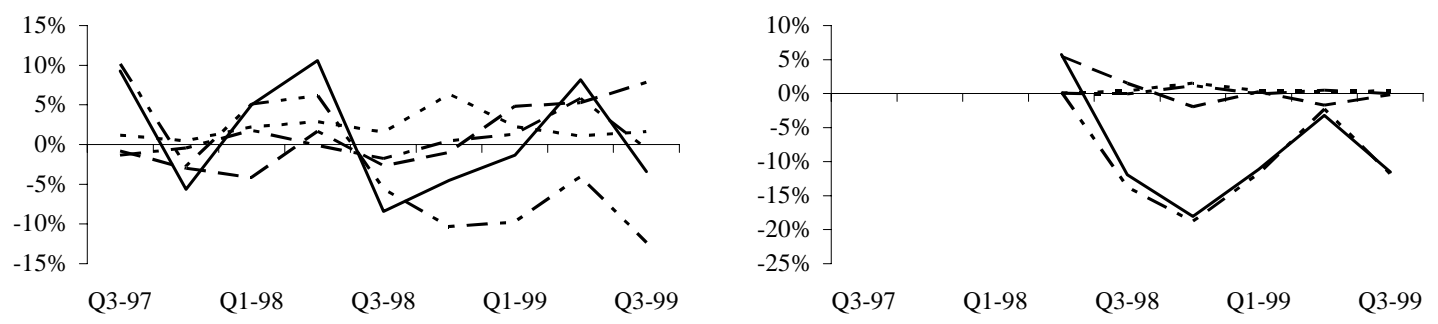

Slovak Republic

South Africa
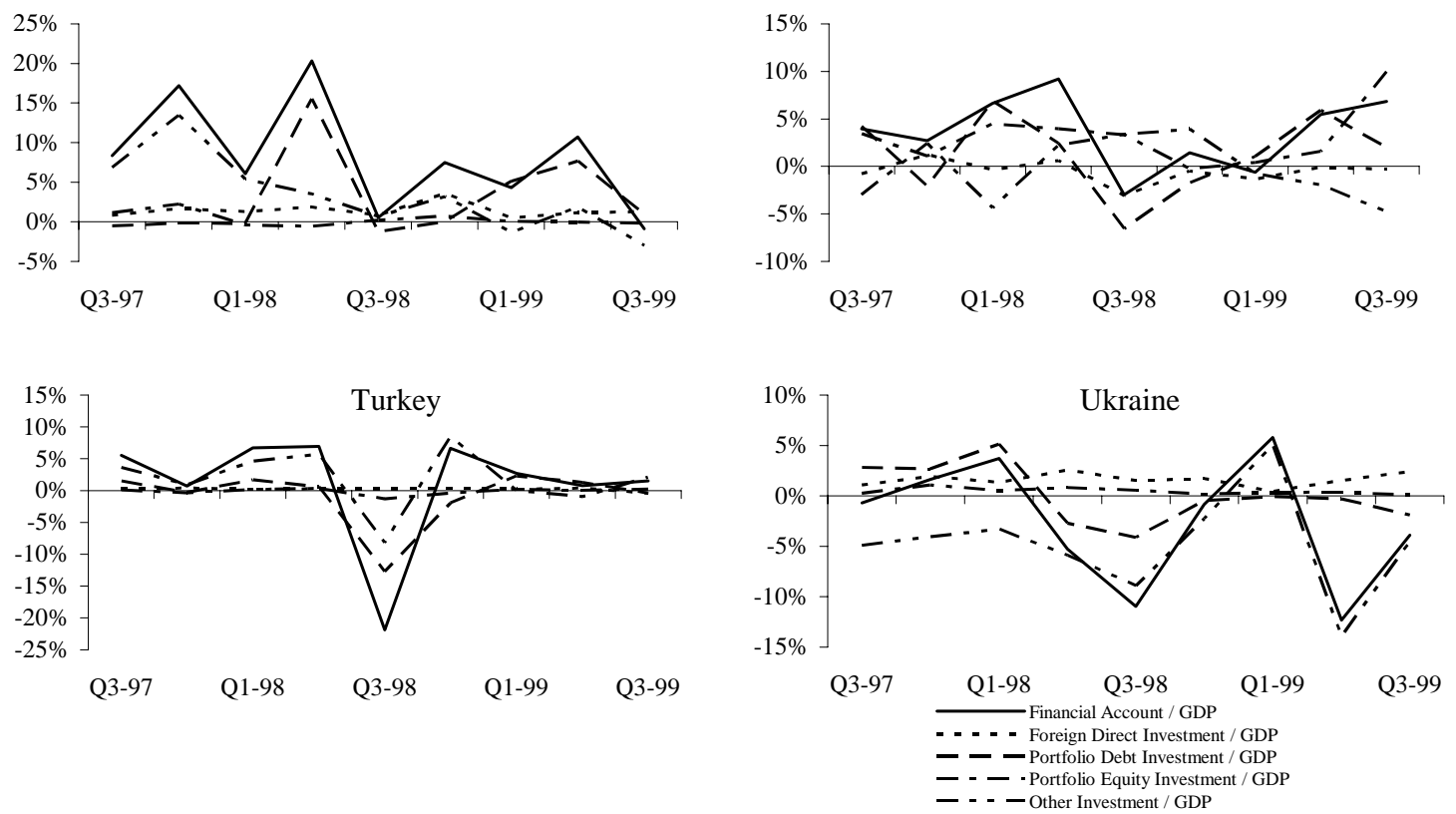

Source: IMF, Balance of Payments Statistics.

Note: "Other investments" in this chart includes bilateral official flows but excludes multilateral official flows. 
16

Figure 3. Consensus Forecasts for the Following Year (Real GDP Growth in Percent)

Korea 1997

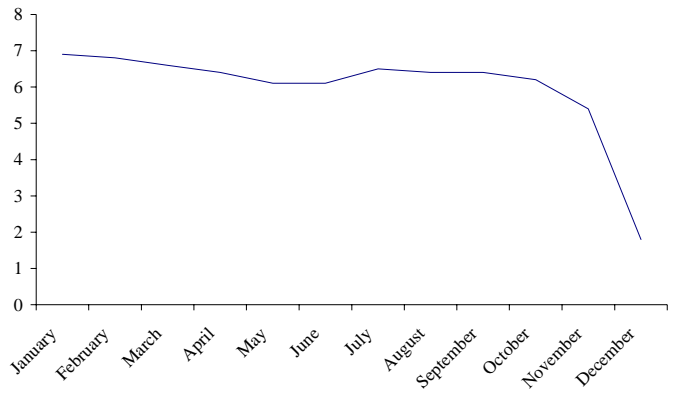

Crisis in Thailand began in July 1997

Thailand 1997

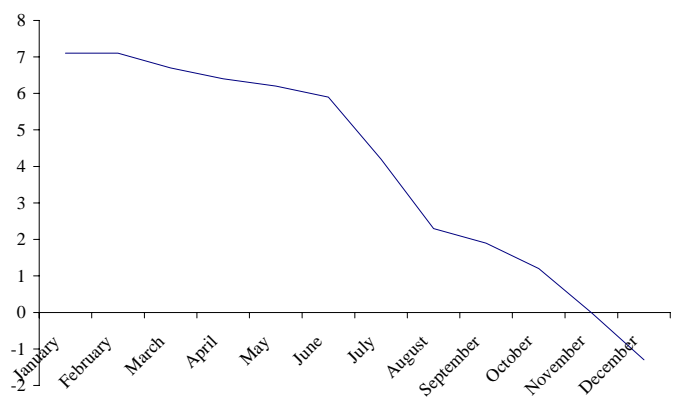

Crisis in Thailand began in July 1997

Peru 1998

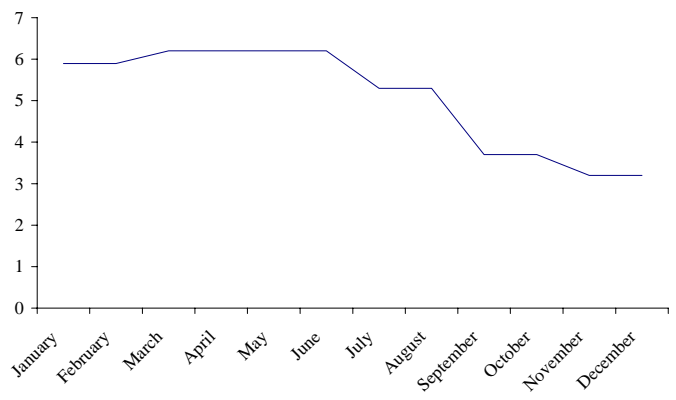

Crisis in Russia began in August 1998

Slovenia 1998

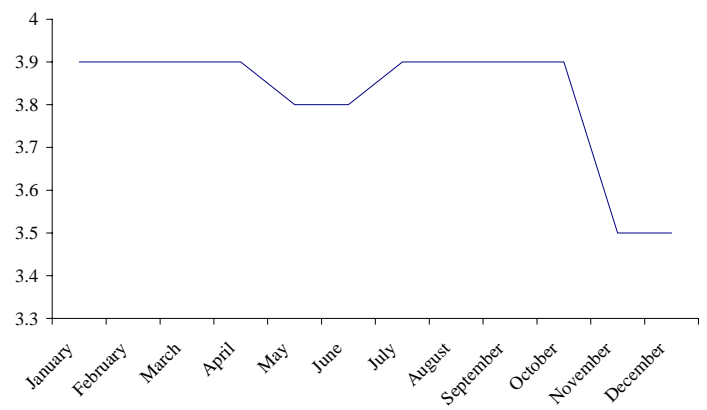

Crisis in Russia began in August 1998
Philippines 1997

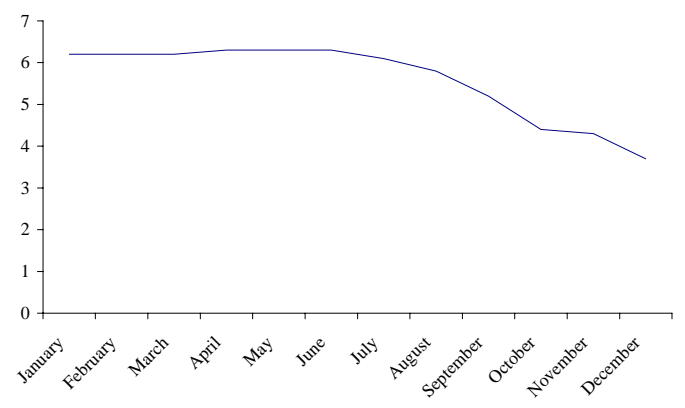

Crisis in Thailand began in July 1997

Estonia 1998

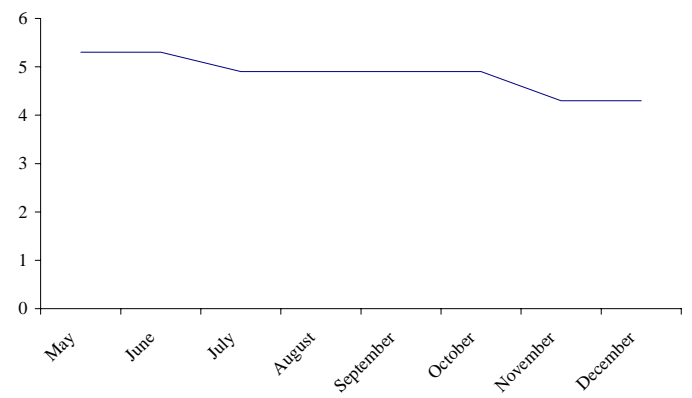

Crisis in Russia began in August 1998

Russia 1998

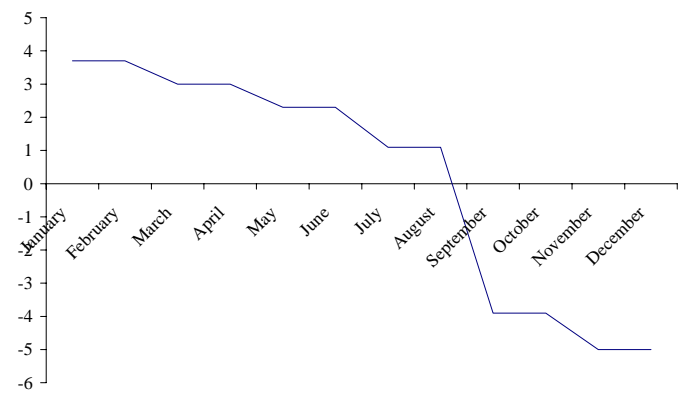

Crisis in Russia began in August 1998

Ukraine 1998

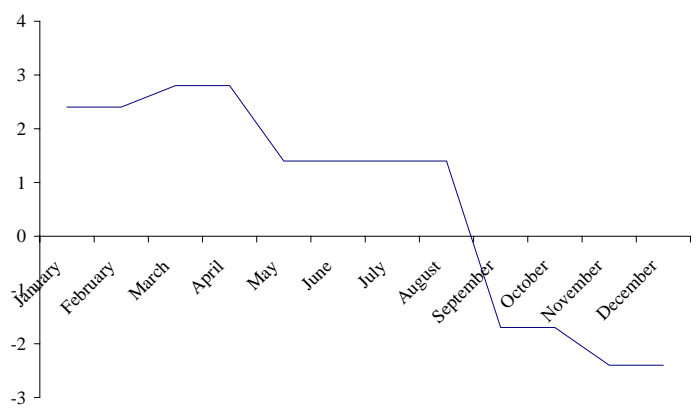

Crisis in Russia began in August 1998 


\section{Figure 3 (concluded) Consensus Forecasts for the Following Year (Real GDP Growth in Percent)}

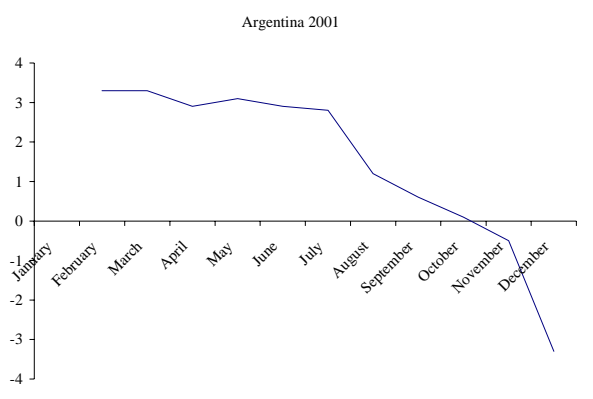

Currency board in Argentina collapsed in January 2002

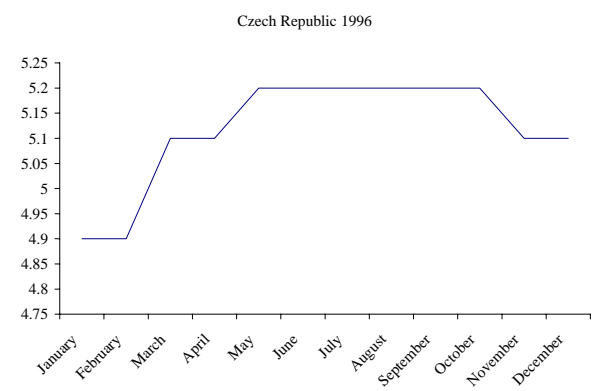

Mexico 1994

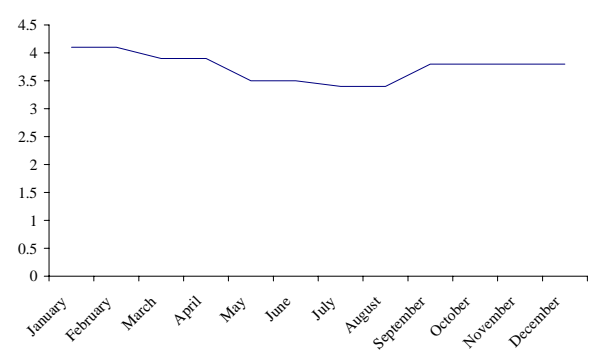

Exchange rate in Mexico collapsed in December 2004.

Turkey 2000

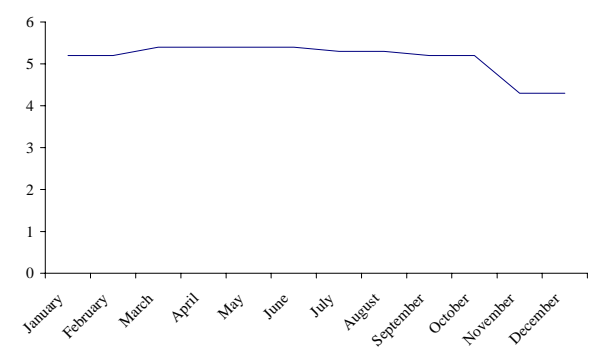

Exchange rate in Turkey fell sharply in January 2001.
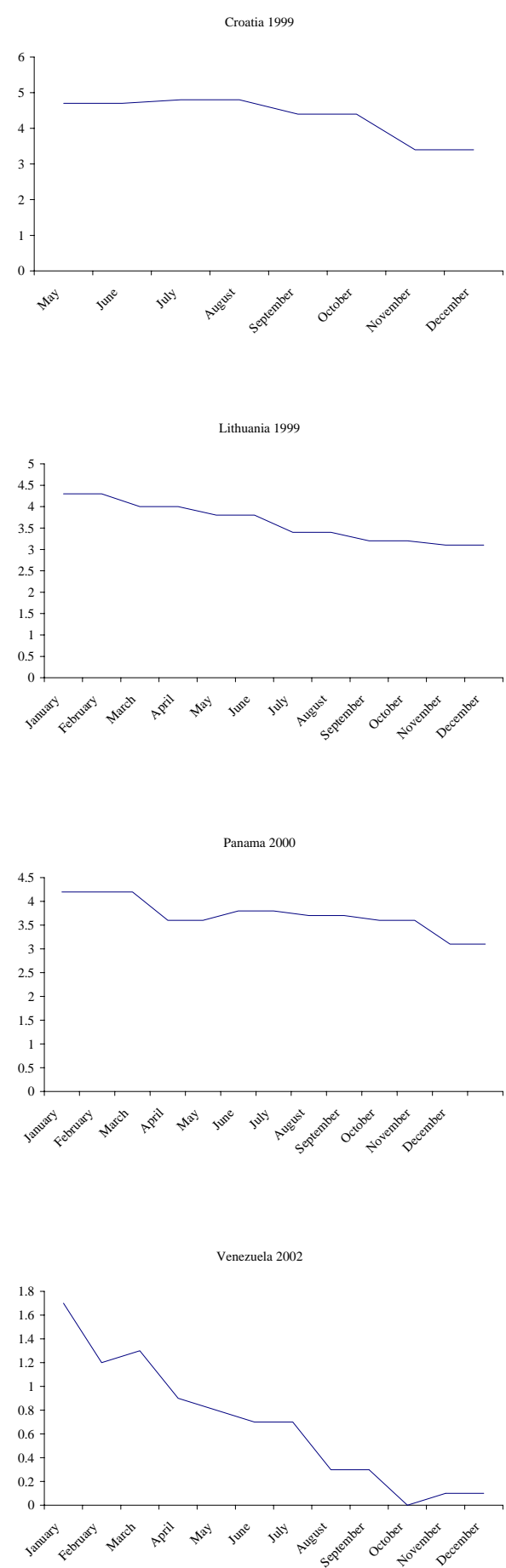
suggests that it would be unlikely for fire-sale FDI to match any decline in FDI so as to yield such exact stability in so many countries. Thus, it is an open question whether fire-sale FDI is a phenomenon of macroeconomic relevance in countries other than Korea and Thailand. Second, and more important, one might wonder whether FDI is failing to provide protection from sudden stops when domestic agents take a capital loss and then sell FDI (in a fire-sale) to foreign investors, who buy cheap assets in the aftermath of the crisis. Although it is true that domestic agents incur a capital loss in this case, a similar loss affects foreign investors who held FDI prior to the crisis. Moreover, as stated in the introduction, this paper focuses on the behavior of various types of flow, leaving the cyclical pattern of returns on the resulting stocks as a topic for further investigation.

\section{Conclusions And Possible Extensions}

There has been considerable interest in the question of whether some forms of external financing help protect emerging markets from volatility and, in particular, render sudden stops in external financial flows less likely or less damaging. Previous studies have drawn on important episodes or provided a partial analysis of stylized facts. This paper has sought to systematically document a thorough list of stylized facts on the behaviour of various types of financial flows, and to focus on times of sudden stop, considering a large panel of advanced, emerging, and developing countries for 1970-2003. The evidence suggests that differences across types of flows are limited with respect to volatility, persistence, cross-country comovement, and correlation with growth at home or in the world economy. However, consistent with conventional wisdom, FDI is found to be the least volatile form of financial flows when taking into account the average size of net or gross flows. The differences become striking during episodes of sudden stop: in such episodes, equity-like forms of financial flow and FDI in particular are very stable. Other flows, including portfolio debt flows and, to a greater extent, bank flows and trade credits, account for the sudden stops.

Although causal relationships in this context are difficult to establish, in conducting our analysis we have sought to address issues of possible reverse causality that might affect the interpretation of the results, and have attempted to focus on the impact of sudden stops that were not clearly triggered by worsening expectations of economic performance in the countries under consideration. We have shown that the sudden stops considered here were not preceded by declines in forecast growth. Moreover, the results hold when considering the response of different components of financial flows at the quarterly frequency around the Russia/LTCM crisis of August 1998 — an event that we view as clearly exogenous to country-specific variables for most emerging markets.

While many possible extensions to the analysis could be considered, three potential extensions are worth highlighting. First, the analysis could be repeated controlling for the potential determinants of financial flows, and thus focusing on the residuals from panel regressions using alternative sets of potential explanatory variables (macroeconomic variables or even just—as a summary measure of fundamentals—growth forecasts). 
However, we do not expect that the main results would change, because fundamentals have little explanatory power for financial flows (Broner and Rigobon, forthcoming). Second, one could analyze the behavior of returns on the various types of flows, showing that returns on equity-like forms of external liabilities (FDI and porfolio equity) are far lower than on debtlike liabilities in times of sudden stops. This would make it possible to measure the precise extent to which equity-like types of finance allow domestic producers to share risk with foreign investors. Third, moving to the consequences of financial flows, one could ask whether sudden stops in financial flows (and, more specifically, in non-FDI flows) have a large, adverse impact on the deviation of output from forecast output-suggestive evidence that the causal relationship goes from capital flows to output, rather than the other way around. We leave these issues for further research. 


\section{REFERENCES}

Aguiar, Mark, and Gita Gopinath, 2005, "Fire-Sale Foreign Direct Investment and Liquidity Crises,” The Review of Economics and Statistics, Vol. 87, No. 3, pp. 439-52.

Albuquerque, Rui, Norman Loayza, and Luis Servén, 2005, “World Market Integration through the Lens of Foreign Direct Investors,” Journal of International Economics, Vol. 66, No. 2, pp. 267-95.

Broner, Fernando, and Roberto Rigobon, forthcoming, "Why are Capital Flows so much more Volatile in Emerging than in Developed Countries?” External Financial Vulnerability and Preventive Policies, Eighth Annual Conference of the Central Bank of Chile.

Calvo, Guillermo, Alejandro Izquierdo, and Luis-Fernando Mejia, 2004, “On the Empirics of Sudden Stops: The Relevance of Balance-Sheet Effects,” NBER Working Paper No. 10520 (Cambridge, Massachusetts: National Bureau of Economics Research).

Calvo, Guillermo, Leonardo Leiderman, and Carmen Reinhart, 1993, “ Capital Inflows and the Real Exchange Rate Appreciation in Latin America,” Staff Papers, International Monetary Fund, Vol. 40, pp. 108-51.

Chuhan, Punam, Gabriel Perez-Quiros, and Helen Popper, 1996, “International Capital Flows: Do Short-Term Investment and Direct Investment Differ?” Policy Research Working Paper 1669 (Washington: World Bank).

Claessens, Stijn, Michael P. Dooley, and Andrew Warner, 1995, "Portfolio Capital Flows: Hot or Cold?” The World Bank Economic Review, Vol. 9. No. 1, pp. 153-74.

Dornbusch, Rudiger, Ilan Goldfajn, and Rodrigo O. Valdes, 1995, “Currency Crises and Collapses,” Brookings Papers on Economic Activity, No. 2, pp. 219-70.

Faria, André, and Paolo Mauro, 2004, "Institutions and the External Capital Structure of Countries,” IMF Working Paper No. 04/236 (Washington: International Monetary Fund).

Fernández-Arias, Eduardo, 1996, “The New Wave of Private Capital Flows: Push or Pull?” Journal of Development Economics, Vol. 48, pp. 389-418.

Fernández-Arias, Eduardo, and Ricardo Hausmann, 2001, "Is Foreign Direct Investment a Safer Form of Financing?” Emerging Markets Review, Vol. 2, pp. 34-49.

Guidotti, Pablo, Sturzenegger, Federico, and Agustin Villar, 2004, "On the Consequences of Sudden Stops,” Economia, Vol. 4, No. 2, pp. 171-203. 
Lipsey, Robert E., 2001, “Foreign Direct Investors in Three Financial Crises,” NBER Working Paper No. 8084 (Cambridge, Massachusetts: National Bureau of Economics Research).

Prasad, Eswar S., Kenneth Rogoff, Shang-Jin Wei, and Ayhan Kose, 2003, "Effects on Financial Globalization on Developing Countries: Some Empirical Evidence,” IMF Occasional Paper No. 220 (Washington: International Monetary Fund).

Rogoff, Kenneth, 1999, International Institutions for Reducing Global Financial Instability, Journal of Economic Perspectives, Vol. 13, pp. 21-42.

Sarno, Lucio, and Mark P. Taylor, 1999, "Hot Money, Accounting Labels and the Permanence of Capital Flows to Developing Countries: an Empirical Investigation," Journal of Development Economics, Vol. 59, No. 2, pp. 337-64.

Wei, Shang-Jin, 2001, "Domestic Crony Capitalism and International Fickle Capital: Is There a Connection?” International Finance, Vol. 4, pp. 15-45.

World Bank, 1999, Global Development Finance (Washington: World Bank). 